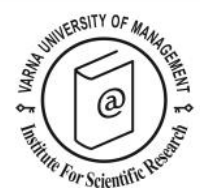

\title{
Delving into the Role of Celebrity Chefs and Gourmets in Culinary Destination Marketing
}

\section{Sehnaz Demirkol ${ }^{1}$ and Ibrahim Cifci ${ }^{2 *}$}

\footnotetext{
${ }^{1}$ Department of Tourism Management, Faculty of Economics, Istanbul University, Istanbul 34452, Turkey, E-mail: sdemirkol@istanbul.edu.tr

${ }^{2}$ Department of Tourism Management, Faculty of Economics, Istanbul University, Istanbul 34452, Turkey, E-mail: ibrahim.cifci@istanbul.edu.tr

* Corresponding author
}

\begin{abstract}
This paper aims to explore the role of celebrity chefs and gourmets in culinary destination marketing based on the perceptions of celebrity chefs and gourmets. Drawing on qualitative data collected through 20 semi-structured interviews with celebrity chefs and gourmets in Turkey, the findings highlight the role of these celebrities in culinary destination marketing. This role is shaped through three key interconnected dimensions; namely, provocativeness, credibility, and supportiveness. The study is among the first attempts to explore, in an integrated manner, the role of celebrity chefs and gourmets from a destination marketing perspective. The study makes several theoretical contributions and proposes practical implications for practitioners in both destinations and firm levels.
\end{abstract}

Keywords: Celebrity, Chefs, Gourmets, Destination marketing, Culinary marketing

Citation: Demirkol, S. \& Cifci, I. (2020). Delving into the Role of Celebrity Chefs and Gourmets in Culinary Destination Marketing. European Journal of Tourism Research 26, 2603 


\section{Introduction}

Numerous studies highlight the role of celebrity endorsement in enhancing favourable destination image and attracting larger numbers of tourists to destinations (e.g., Veen, 2008; Lee, et al., 2008; Glover, 2009; Veen \& Song, 2010; 2014; McCartney \& Pinto, 2014; Weir \& Weir, 2015; Fath, et al., 2017; Chan, Lee, \& Wong, 2018). Therefore, benefitting from celebrity gourmets and chefs can fit well in today's gastronomy trends. For instance, Hong Kong (DMOs) has recently embraced the key roles of celebrity chefs and gourmets for promoting their destination as a famous culinary spot (Hong Kong Tourism Board, 2020).

Employing celebrity endorsers assists products/brands and prevents other advertising complexities, contributing to positive attitudinal and behavioural responses which eventually enhances these products/brands' position in the market (Doss, 2011). Celebrity-endorsed destinations can positively enhance travellers' attitudes and behaviours (Brien, 2011). Celebrities might also play a significant role in allowing travellers to construct their identity and express their self-images because of the congruence between the celebrity, endorsed destination, and the consumer (Rinka \& Pratt, 2018). Therefore, tourism businesses and destination authorities have recognized the importance of celebrity endorsement for marketing and thus, begun to employ celebrities (Glover, 2009).

Numerous benefits can be derived through using celebrities such as making products memorable, creating a positive image, raising the brand's familiarity and recognition, attracting the attention of elite customers, and underpinning global campaigns or local providers (Erdogan, 1999; Agrawal \& Kamakura, 1995; Lee, et al., 2008; Veen \& Song, 2014; Yen \& Croy, 2016). It is important, therefore, to investigate the role of celebrity gourmets and chefs as a marketing tool to evaluate the impact of those individuals in culinary destination marketing. Gourmets and chefs are traditionally accepted as celebrities who have usually developed expertise in food and beverage entitling them to influence and direct trends in modern gastronomy (Svejenova, et al., 2015). Therefore, flavour creative chefs and the gourmets who can inspire and attract potential customers have a central role in creating the product (meal) and therefore generating greater revenues for businesses and eventually for destinations.

Previous studies on celebrity gourmets and chefs have addressed several issues including these celebrities' adoption of social media (Clarke, Murphy, \& Adler, 2016), their role in enhancing tourism experiences (Abidin, Panchal, \& Thirumaran, 2017) and their social influences in general (Jones, Freeth, \& Costa, 2013; Lane, \& Fisher, 2015). A holistic investigation of the role of celebrity gourmets and chefs in culinary destination marketing is still lacking. Therefore, the present exploratory paper offers new and deeper insights into the celebrity chef and gourmet phenomenon. The current investigation is therefore intended to fill this gap by drawing on qualitative data from celebrity gourmets and chefs in Turkey to identify variables that determine celebrity endorser roles in culinary destination marketing. Given the scarcity of studies addressing this topic, this research makes significant theoretical and practical contributions. The findings are expected to help improve the design of marketing strategies, reach an understanding of why consumers follow celebrity chefs and gourmets and what they expect before choosing foods, restaurants, and eventually a given destination. The findings of the current study will help establish more effective marketing strategies from the customer point of view. The study contributes to the existing literature on destination marketing and endeavours to shift focus to gourmets and chefs as endorsement sources within the culinary destination marketing. 


\section{Literature review}

\section{Culinary destination}

Destination specific authentic food and beverages contribute to the tourism value of a destination (Okumus et al., 2007; Karim \& Chi, 2010; Okumuș et al., 2013; Robinson \& Getz, 2014; Okumus \& Cetin, 2018). Therefore, tourism has both a considerable impact on food supply and demand in a destination (Hall \& Mitchell, 200o). Consuming exotic food and beverages in a destination creates values for travellers (Sanchez, et al., 2006; Jensen \& Hansen, 2007; Choe \& Kim, 2018) and thus generates a reciprocal benefit while travellers provide a market for these products (Boyne et al., 2003). The desire to discover new flavours or terroirs' wine (Hall \& Sharples, 2003; Brown, 2010; Montella, 2017), visit world-famous chefs' restaurants, and participate in food festivals (Smith \& Costello, 2009) are among the key motivations of today's gastronomy tourism. The food enthusiasts enjoy exploring new flavours. Therefore, the destinations where the cuisine is developed have received recognition by food travellers in recent years (Rachao et al. 2019). This recognition has increased some destinations' reputation and attracted international food travellers (Nelson, 2015). For instance, Peru has significantly increased its tourism revenue in recent years due to its culinary destination image (Larson \& Poudyal, 2012).

The tourist's destination selection and motivation to experience territorial flavours are greatly affected by several sources of information (Pawaskar \& Goel, 2016; Okumus \& Cetin, 2018). As a source of information, media can influence tourists in terms of what, how, and where to eat and also can provide them with several benefits including cooking, socializing, enhancing well-being and having a good lifestyle (Berkman \& Gilson, 1986; Fodness \& Murray, 1998). All those experiences add value to the destination core attributions and provide an opportunity for travellers to create a connection between themselves and the destination (Cetin \& Bilgihan, 2016; Kim, 2018). Tsai \& Wang (2017) note that tourists gain different experiences when they consume local foods while fulfilling their mere physiological needs.

Local food can also boost the identity of the destination because it is closely associated with a destinations' lifestyle, culture, belief, and heritage (Everett \& Aitchison, 2008) thus encouraging faviourable behavioural intentions (Kivela \& Crotts, 2005; Larsen, 2007; Mckrecher et al., 2008). Given that food can also be considered as a mirror that can reflect the belonged host society, it can be used as a strategy to promote a country's culture (Trubek, 2008). As noted by Okumus et al. (2013), local cuisine has become a key factor in destination branding by local authorities. Travellers develop an emotional relationship with the destination core attributes to express their self-personality (Park, et al., 2010; Phillips, et al., 2010; Whiting \& Hannam, 2015; Sirgy, 2018; Lochrie, et al., 2019). Thus, the culinary culture of destinations has become one of the prominent elements that destination authorities take into account in creating an image and branding to persuade potential tourists to visit (Okumus et al., 2013; Björk \& Kauppinen-Räisänen, 2016; Tsai \& Wang, 2017; Okumus \& Cetin, 2018). The brand image of destinations is based on the accumulation of information that travellers obtain from diverse sources (Nelson, 2016). Celebrity endorsement is one effective information source that generates a congruence between travellers' ideal-self and the brand they endorse with their celebrity image (Choi \& Rifon, 2012).

\section{Celebrity endorsement and destination marketing}

Celebrity experts offer a bridge for integration between the market and the public who may have anxieties about trying new things (Powell \& Prasad, 2007). Many people imitate and impersonate celebrities' behaviour by aspiring to share the same values and lifestyles of celebrities as a way to enhance their own self-esteem (Muda, et al., 2017. This drives people to choose and use the products/ brands associated with those celebrities due to the desire to become like them. Rinka and Pratt (2018) explained this phenomenon by adopting social influence theory which is based on consumers' 
conformed and hence changed attitudes and behaviours through advocates from another person due to the desire for imitating or becoming that person. Therefore, celebrities can be regarded as important figures who draw consumers' attention and lead them to engage with the endorsed product/brand thus internalizing the transferred values for constructing and expressing their self-concept (Dwivedi, Johnson, \& McDonald, 2016).

Much research into celebrity endorsements has addressed various issues. Broadly speaking, endorsement literature is shaped into five study streams. The first stream explains the theories and models of endorsements. For instance, 'the match-up theory' is related to the endorsement role in consumers' attitudes and behavioural intentions (Kamins, 1989;1990). Kamins and Gupta (1994) stated that a good match between parties generally provides congruency, similarity, relevance, and consistency. Another model, 'the source attractiveness model', evaluates the attractiveness of celebrities based on three attributes: similarity, familiarity and liking (McGuire, 1985); 'meaning-transfer model', celebrities transfer meanings to a brand via the endorsement (McCracken, 1989; Halonen-Knight \& Hurmerinta, 2010; Roy, 2018). Consider the importance of meaning transfer in terms of bonding connection with the audience. Those individuals generally write in culinary magazines, broadcast in TV shows, or share their comments on social media. Especially social media comments about a specific food or restaurant creates a popular icon in attracting eating out in situations of mobility hence redesigning the destination as a tourists' attractive place (Everett, 2016; Onorati \& Giardullo, 2020). Given the wide reach and immense persuasive influence of social media in tourism, celebrities engage with their wide audience in online platforms and lead them with their recommendations which depends on trustworthiness and the quality of the provided information (Magno \& Cassia, 2018).

The second stream identifies the attributes of endorsers. Effective endorsers display demonstrable attributes for meaning transfer such as trustworthiness, believability, persuasiveness, likeability, expertise, attractiveness, competence, familiarity, identification performance, values, and cogent power (Amos et al., 2008; Ketchen et al., 2008; Magnini et al., 2008; Ohanian, 1990; 1991; Till \& Busler, 2000; McCartney \& Pinto, 2014; Jain \& Roy, 2016). The third stream explains the effect of endorsement on advertising and is widely known as 'source credibility'. It is widely accepted in the field that celebrity endorsers bring credibility to advertising messages (Choi \& Rifon, 2007). Celebrity endorsers' credibility was widely identified by three factors: attractiveness, expertise, and trustworthiness (Ohanian, 1991). Attractiveness is referred to as the confidence in the information source (Erdogan, 1999), expertise is identified as the perceived ability of the celebrities to make valid assertions (McCracken, 1989), and trustworthiness is defined as the confidence of celebrities in engaging communication with the audience (Amos, Holmes, \& Strutton, 2008). In another widely adopted study Erdogan (1999), stated that trustworthiness was specifically represented by dignity, believability, and honesty. According to Van Der and Song (2014), especially trustworthiness and expertise were particularly attributed as key factors that have a positive role in tourists' travel intention.

The fourth stream explains the effect of a good or mismatch between an endorser and a product/brand (Amos, et al., 2008; Till \& Busler, 2000; Marshall, et al., 2008; Koerning \& Boyd, 2009; Till \& Shimp, 1998; Kamins, 1989;1990). The positive consumers' perceptions of an endorsed product/brand may move immediately in the same direction (Knittel \& Stango, 2014; Yang, 2018). This situation mentioned in literature is a double-edged sword (Muda, et al., 2017). Scholars highlight the importance of the right celebrity endorser to avoid the risks of wrong decisions that can be made for a product/brand (Veen, 2008; Halonen-Knight \& Hurmerinta, 2010). These can be summarized as (1) Vampire effect (i.e., the endorsed product/brand is overshadowed by a celebrity) (Erdogan, 1999; Erdogan \& Baker, 200o; Yang, 2018; White, et al., 2009), (2) over-endorsement, (3) change in consumer choice or resistance to 
endorsements (Doss, 2011), and (4) an undesirable celebrity image change or public scandal (Till \& Shimp, 1998; Knittel \& Stango, 2014). In tourism destinations, a right match-up in selecting the optimum celebrity characters can provide an enduring engagement in leading and enhancing the knowledge and activity for that destination (Chan, Lee, \& Wong, 2018). Therefore, only the right celebrity can induce individuals to create emotional bonds and hence engage with endorsed destinations in terms of enhancing awareness (Croy, 2010). The fifth evaluates the efficacy of endorsement in promoting a brand/product. For instance, researchers addressed two particular issues on the efficacy of the celebrities: (1) the popularity of the celebrity for attracting individuals' attention to the endorsed product/brand; (2) the attractive and likeability quality of celebrities in transferring their images between parties (Atkin \& Block, 1983; Mishra, Roy, \& Bailey, 2015; Chen, Raab, \& Chen, 2017).

\section{An approach to celebrity chefs and gourmets}

Celebrity chefs and gourmets have been acknowledged as role models for travellers (Jones, 2009; Powell \& Prasad, 2010; Johnston et al., 2014; Chen et al., 2017; Barnes, 2017). Considering the social and cultural role of celebrity chefs, these individuals are considered stars who transform a desirable marketing tool utilized pervasively in the food industry (Kim, et al., 2014; Fuste-Forne, 2018). Celebrity chefs have become culinary leaders in the scope of both tangible restaurants and intangible social media (Chen, Raab, \& Chen, 2017). Therefore, celebrity chefs' restaurants create a crucial value for the food and beverage industry in tourism destinations (Chen et al., 2017) and thus several tourism destinations strive to benefit from this trend (Lee et al., 2008; Glover, 2009; Yen \& Croy, 2013; Yen \& Teng, 2015). For instance, Kim et al. (2013) found that chefs are one of the important endorsers that positively affect tourists' attitudinal or behavioural responses. Moreover, Henderson (2018) emphasized the importance of local-chefs rather than using nonlocal-chefs because of the travellers' desire for authenticity.

Celebrity gourmets can also play an important role in reducing some travellers' anxiety for experiencing new foods at destinations (Taspinar \& Temeloglu, 2018). The most important part of the celebrity gourmets' role in tourism destinations may be attributed to presenting new, unusual, and exotic foods to his or her readership that are not normally found in a tourists' geographic location (Johnston \& Cairns, 2009). Experiencing authentic food influences the decision of tourists' food consumption (Burusnukul, Binkley \& Sukalakamala, 2011; Coughlan \& Saayman, 2018). Beyond providing information on the how, where, and what to eat in a destination, celebrity gourmets also provide some comments on a dish or restaurant in progress. They engage with a range of important food-related issues such as food production and consumption including food safety and security, sustainable agriculture, biodiversity, and genetic modification and, food-related health issues (Brien, 2011).

\section{Methodology}

The power of the media has recently changed the social status of chefs (Pizam, 2016) as well as gourmets (Taspinar \& Temeloglu, 2018) which enable them to endorse destinations as a source of information for attracting a greater number of tourists. Thus, celebrity chefs and gourmets were considered as an appropriate study population to explain the role of celebrity endorsement phenomenologically in culinary destination marketing. Therefore, the key objective of this study is to identify the key dimensions that determine celebrity endorsers' role in culinary destination marketing based on the views of those celebrity individuals.

To collect data, semi-structured interviews were conducted over a period of four months between June to September 2017. Celebrity chefs and gourmets in Turkey constituted the population of the study. The criteria of defining a celebrity gourmet and chef include: a high media profile, having bestseller gastronomy books, writing in the newspapers/magazines, having a high following on social media, 
owning/running a first-class restaurant, and having reputable achievement awards. The participant profile is presented in Table 1 . After identifying the criteria for inclusion, a series of open-ended questions were identified based on an extensive literature review. The questions were first reviewed by two different academicians who have a solid and considerable background. Second, a pilot test with five participants was conducted to improve the face validity of the questions. Based on the pilot test minor modifications were made. For instance, participants were asked about their particular tendencies to share their knowledge and experience with the public and what effect there was on the food, restaurants and therefore, destination marketing practices.

Table 1. Participants Profile

\begin{tabular}{|c|c|c|c|c|c|}
\hline Category & Number & $\begin{array}{l}\text { Education } \\
\text { Level }\end{array}$ & $\begin{array}{l}\text { Position/self- } \\
\text { description }\end{array}$ & $\begin{array}{c}\text { Year of } \\
\text { experience }\end{array}$ & $\begin{array}{l}\text { Number of } \\
\text { followers on } \\
\text { social media }\end{array}$ \\
\hline \multirow{10}{*}{ Chef } & $C_{1}$ & Undergraduate & $\begin{array}{l}\text { Restaurant \& cafe owner } \\
\text { chef }\end{array}$ & $10+$ & 1421 \\
\hline & $C_{2}$ & $\begin{array}{l}\text { Primary school } \\
\text { graduate }\end{array}$ & $\begin{array}{l}\text { Restaurant \& bar owner } \\
\text { chef }\end{array}$ & $15^{+}$ & 10100 \\
\hline & $C_{3}$ & Undergraduate & Restaurant chef & $35^{+}$ & 20400 \\
\hline & $\mathrm{C}_{4}$ & Undergraduate & Restaurant chef & $35^{+}$ & 18500 \\
\hline & $\mathrm{C}_{5}$ & Undergraduate & Restaurant chef & $40+$ & 2630 \\
\hline & C6 & Post-graduate & Restaurant chef & $35^{+}$ & 29800 \\
\hline & $\mathrm{C}_{7}$ & Post-graduate & Restaurant chef & $10+$ & 6584 \\
\hline & $\mathrm{C} 8$ & Post-graduate & Restaurant chef & $35^{+}$ & 4532 \\
\hline & $\mathrm{C}_{9}$ & Undergraduate & Restaurant chef & $40+$ & 2696 \\
\hline & $\mathrm{C}_{10}$ & Undergraduate & Restaurant and bar chef & $30+$ & 8526 \\
\hline \multirow{10}{*}{ Gourmet } & G11 & Post-graduate & $\begin{array}{l}\text { Food Journalist and } \\
\text { researcher }\end{array}$ & $15^{+}$ & 2790 \\
\hline & G12 & Post-graduate & $\begin{array}{l}\text { Food Journalist and } \\
\text { researcher }\end{array}$ & $20+$ & 2477 \\
\hline & $\mathrm{G} 13$ & Undergraduate & Food researchers & $20+$ & 4720 \\
\hline & $\mathrm{G} 14$ & Undergraduate & Food researchers & $20+$ & 12400 \\
\hline & $\mathrm{G}_{15}$ & Undergraduate & Food researchers & $20+$ & 48400 \\
\hline & $\mathrm{G} 16$ & Undergraduate & $\begin{array}{l}\text { Food Journalist and } \\
\text { researcher }\end{array}$ & $15^{+}$ & 373000 \\
\hline & $\mathrm{G} 17$ & Undergraduate & $\begin{array}{l}\text { Food Journalist and } \\
\text { researcher }\end{array}$ & $20+$ & 92000 \\
\hline & $\mathrm{G} 18$ & Undergraduate & $\begin{array}{l}\text { Food Journalist and } \\
\text { researcher }\end{array}$ & $30+$ & 303000 \\
\hline & G19 & Undergraduate & $\begin{array}{l}\text { Food Journalist and } \\
\text { researcher }\end{array}$ & $20+$ & 14900 \\
\hline & $\mathrm{G}_{20}$ & Undergraduate & $\begin{array}{l}\text { Food Journalist and } \\
\text { researcher }\end{array}$ & $15^{+}$ & 16000 \\
\hline
\end{tabular}

The study population involves Turkey-based celebrity chefs and gourmets since it was suggested that domestic celebrities were generally more effective than foreign in terms of delivering advertising messages to the targeted segment (Van Der \& Song, 2014; Fath, et al., 2017). An estimation of the study 
population is challenging given the absence of reliable official data of the numbers of chefs and gourmets in Turkey. Given the limited access to the study population, the snowball sampling technique was employed. Two chefs and one gourmet were initially reached. After interviews were conducted, they were asked to provide contacts with other potential participants. At the end of this process, interviews were conducted with 10 celebrity chefs and 10 gourmets. With the data collected from these 20 interviews, the theoretical saturation level was reached and therefore conducting further interviews would not have generated significant additional insights (Glaser \& Strauss, 1967). With permission of the participants, both audio recordings and notes were taken in the interviews. All interviews were conducted in restaurants and lasted around 45 minutes.

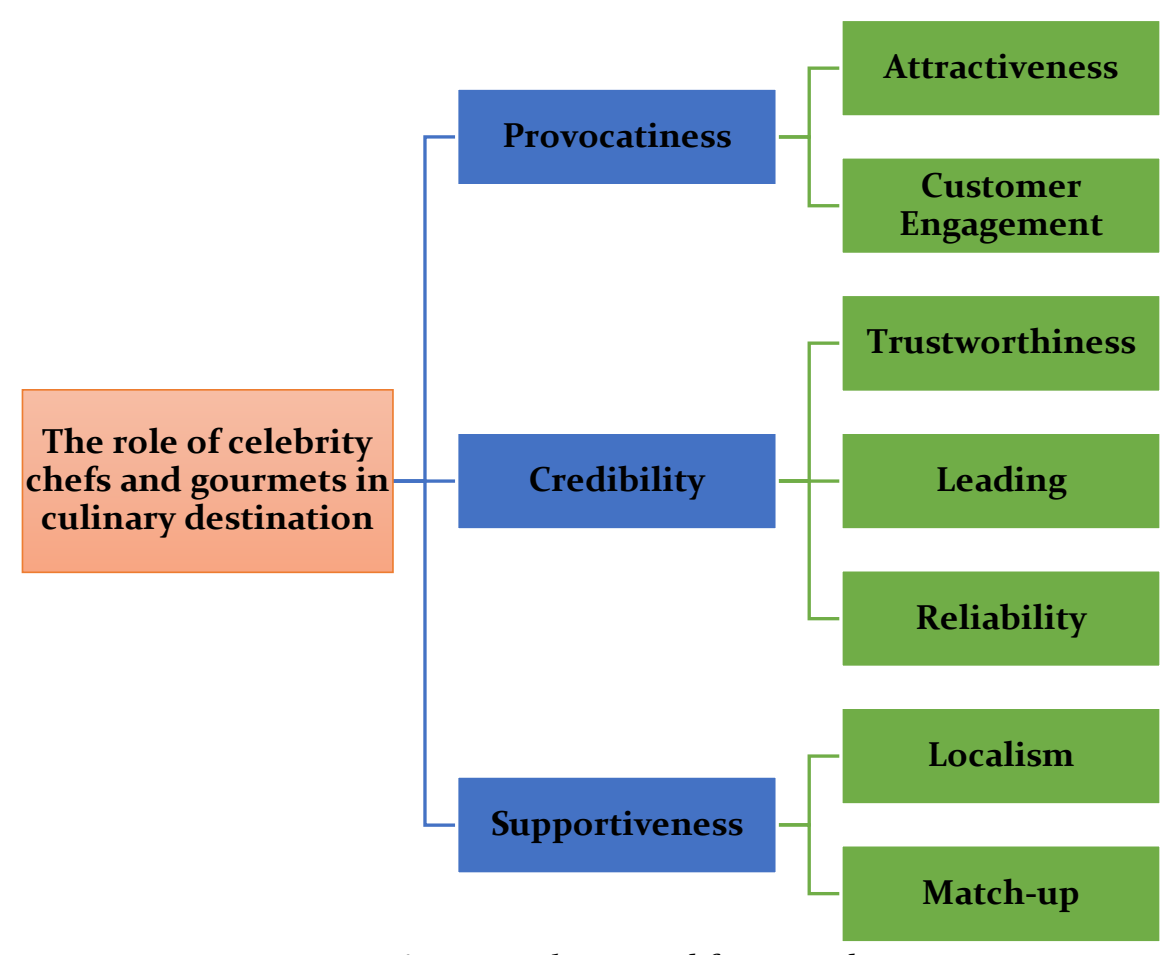

Figure 1. Theoretical framework

The data was analysed using the content analysis method systematically and involved the categorization of common themes. All of the participant responses were read several times and scrutinized independently by each researcher to reach a common and overall meaning before common themes were coded and extracted (Braun \& Clarke, 2006). Later, all interviews were analysed and grouped into categories to determine the common factors of celebrity chefs and gourmet's role in culinary destination marketing. The data was analysed by using the Nvivo 12 Pro package program which is frequently used in qualitative research. Word clouds were drawn related to the themes that the participants intentionally mentioned, and then a data pool consisting of these clouds allowed researchers to make inferences about the main dimensions of the study by considering the previous literature review. For instance, 'trustworthiness' was mentioned by a few participants as one of the important subcategories of the provocativeness role. The comparison to relevant literature showed that trustworthiness was interpreted as one of the main sources of credibility. This approach allowed the authors to create significant links between existing literature (deductive analysis; Gummerson, 2000) and the extracted 
clouds that reflected the important themes from the celebrity chefs and gourmet's explanations (inductive analysis; Creswell, 2007) as well as improve the validity of dimensions. Moreover, all the clouds in the pool were checked several times and arranged before the common themes were identified; clouds which did not really have a theme for the study were removed from the pool; and similar clouds were grouped under higher-order clusters by extracting all commonalities, themes, and descriptions (Patton, 2002; Creswell, 2007). In total, 64 items were extracted and grouped into 7 major contentrelated themes which were provocativeness, credibility, and supportiveness dimensions as shown in Figure 1. In this study, the effectiveness of Nvivo in manual handling of data is also confirmed (Sotiriadou, Brouwers, \& Le, 2014). The original quotations from interviews have also been used to improve the reliability of the findings (Elo \& Kyngas, 2008). Participants' identities were anonymized using $\mathrm{C}$ for chef and $\mathrm{G}$ for gourmet.

\section{Findings and Discussion}

The findings suggest that celebrity chefs and gourmets' roles in culinary destination marketing are a combination of provocativeness, credibility and supportiveness dimensions as listed below in Table 2.

Table 2. Dimensions, Constructs, and Themes of the Analysis

\begin{tabular}{lll}
\hline Dimensions & Construct & Themes \\
\hline Provocativeness & Attractiveness & $\begin{array}{l}\text { stimulating, sociable, communicative, } \\
\text { creativity, competence, perfectionist, } \\
\text { attentive, provoking }\end{array}$ \\
\cline { 2 - 3 } Credibility & $\begin{array}{l}\text { Customer } \\
\text { Euiding, alleviated, experienced, } \\
\text { competence, reputation, professional., } \\
\text { mastery, passion, suggestive, critical }\end{array}$ \\
\hline Trustworthiness & $\begin{array}{l}\text { correctness, sincere, informative, } \\
\text { believable, trained, confidence, } \\
\text { communicative, honesty, convincing, } \\
\text { warmth, kind, persuasiveness }\end{array}$ \\
\cline { 2 - 3 } Supportiveness & Leading & $\begin{array}{l}\text { innovative, expertise, knowledgeable, } \\
\text { educated, informative }\end{array}$ \\
\cline { 2 - 3 } & Reliability & $\begin{array}{l}\text { vilifying, praising, objective, inquisitive, } \\
\text { elaborative }\end{array}$ \\
& Localism & $\begin{array}{l}\text { alleviated, trendiness, inspiring, assisting, } \\
\text { adaptability, prestige, appealing, } \\
\text { underpinning }\end{array}$ \\
\cline { 2 - 3 } & Match-up & $\begin{array}{l}\text { auxiliary valued, enhancing, strengthen, } \\
\text { reinforcing, consolidating }\end{array}$ \\
\hline
\end{tabular}

\section{Provocativeness}

The provocativeness dimension was grouped into two key constructs: attractiveness and customer engagement (Table 1). The content of provocativeness is based on sparking consumer preferences with accurate information. Participants particularly highlighted that companies that relied on the writings of chefs and gourmets performed better in terms of achieving greater sales. This result supports the claim of Kotler et. al. (2006) that the gourmet is more effective than all the promotional efforts of food companies and restaurants in changing the attitudes of the consumer in their decision-making. According to Veen (2008), the celebrity may be more effective if the consumers know that they endorsed the product/brand without having compensation. Otherwise, it created cynicism, especially if people noticed that the celebrity endorser had never used the product/brand. 


\section{Attractiveness}

Foods are presented traditionally in text, images, and promotional materials such as brochures, booklets, catalogs, maps, video clips, and flyers (Okumus et al., 2007; Okumus \& Cetin, 2018). However, all prepared materials were not entirely effective in consumer decision making. Our qualitative data supports this notion and also highlights that the sharing of comments by celebrity chefs and gourmets is only one of the many stimuli that affects the consumer. G1 mentioned:
"We present materials to the people that will enhance their choices [...] A consumer, a restaurant customer, or a wine buyer is being stimulated with thousands of different stimuli [...] In these excitations, what you write is a stimulus, people synthesize all these things. They make a purchase or consumption decision. The writings are not directly effective."

Erdogan (1999) stated celebrities are used to increase message persuasiveness to attract the attention of an audience, thereby enhancing advertising effectiveness. An endorsed product/brand by celebrities affects peoples' attitudes and behaviours. According to Solnick \& Schweitzer (1999) consumers tend to form positive stereotypes of products that are endorsed physically. Participants highlighted what kind of individuals follow their knowledge-based experience and grouped them into two categories. G13 noted: '[...] I believe there are two types of followers. The first ones really want to discover, want to try and are open to newness and travel the Earth. The second is the types that want to follow us in a sense of place.'

\section{Customer Engagement}

Celebrity endorsement provides an opportunity for engagement between customers and the endorsed product/service (Powell \& Prasad, 2007). A celebrity spokesperson offers a channel for consumers to communicate with a brand thus magnifying the effect of the offered products/services on consumers. Given the intangible nature of tourism products, customers tend to rely on cues that are more external. In this case, a celebrity endorsement is becoming prevalent in food marketing. If a celebrity uses the service and makes suggestions through their experience, the consumer will have huge confidence towards a product/brand and is more likely to make a purchase (Magnini et al., 2008). Participants were asked about their roles in influencing public/tourists in culinary destination marketing. The study reveals that participants who shared their experiences with their followers influenced restaurant sales and thus destinations. $\mathbf{C}$ mentioned:

"I shared my experience with a grilled meatball peddler; he was at News in Anadolu Agency. In the same place for 17 years, the peddler had no news, but now he has news. He changed the shop, fixed and cleaned it. After that, customer density began to show in his restaurant [...] I believe that what I share is $100 \%$ effective."

Therefore, celebrities are part of an engagement mechanism that best describes them as "talking labels" who act as cultural intermediaries that transform into boundary objects to connect with food and beverage audiences (Barnes, 2017). Van Der \& Song (2014) verified the mediating roles of celebrity endorsement and according to their study celebrity chefs and gourmets influence peoples' desire to taste new products. This lends support to the study of Rinka and Pratt (2018) in which social influence theory was suggested to explain the consumers' changed attitudes and behaviours towards endorsed product/brand due to inspiration.

On the other hand, those celebrities who write in gastronomic guides (e.g., The Michelin Guide, Red Guide) greatly affect a consumers' food or restaurant choices (Lane, 2013). Participants underscored the 
importance of restaurants in facilitating engagement with the public or tourists. $\mathbf{C}_{\mathbf{7}}$ noted: 'We are a conservative society and we cannot change our habits quickly. So, perhaps we do not follow in that sense of the meal, but I think that we follow in the sense of restaurant.'

\section{Credibility}

Perceived credibility of celebrities has an impact on an endorsed product/brand (Atkin \& Block, 1983; Kamins,1989; Priester \& Petty, 2003). It is perceived as challenging for a chef or a gourmet to share promotional articles, when the purpose of a real chef and gourmet was highlighted as only guiding readers with accurate and sound writing. It is underlined that being honest, sincere and impartial in sharing comments about food and restaurant increases followers and the effectiveness of the writing. By ensuring the credibility role, it will bring the celebrity chefs and gourmets' shared comments an international expansion in the tourism industry and is likely to affect culinary destination marketing establishments. Credibility was grouped into three key constructs: trustworthiness, leading, and reliability as presented in Table 1.

\section{Trustworthiness}

Trustworthiness is considered an important indicator of a celebrity's credibility and involves a celebrity's perceived believability, sincerity, honesty, and integrity, which depends on the targeted audience's perceptions (Ohanian, 1990; Erdogan, 1999). Celebrity chefs and gourmets attempt to foster familiarity, assurance, and trust (Barnes, 2017) by their strong communication skills as well as talent and training. Participants were specially asked to explain what makes their sharing different from other culinary destination marketing activities. Participants emphasized that people should trust gourmets and chefs and emphasized that trust is crucial for consumers to consider gourmets-chefs' recommendations. $\mathbf{9}$ noted: "If the information they give is real., it has an effect, but if the information is not sincere, it goes against the grain."

Furthermore, participants also claimed that by offering sound advice, followers utilize and interpret the knowledge shared by celebrity chefs and gourmets at an individual level in their efforts to determine their own understanding of what 'good food' is. As expressed by $\mathbf{C}_{3}$ :

"Chefs and Gourmets are very important. They determine the market. They can both improve and prevent development. We need to believe them. Your trust for a doctor when he writes your medicine is similar in this case. As long as chefs and gourmets do not mislead people."

\section{Leading}

Nowadays, along with traditional media, celebrities tap into social media and that provides direct access to thousands of eyes for businesses that give a celebrity endorsement (Fuste-Forne, 2018). On the other hand, celebrities transfer their own personal traits and values into advertisements, through the 'meaning transfer process' (Essays, 2018). This process may hold great sway over visitors' culinary understanding because chef and gourmet celebrities have a great culinary philosophy and they transfer this knowledge to their followers by their leading role that attributed to this study. Celebrity chefs and gourmets can offer much valuable information about the destinations' culinary culture. For example, they teach their followers about the cultural history of destination-specific food and the cooking styles of that food at the visiting destination. These characteristics of celebrity chefs and gourmets coincide with the motivation of today's gastronomy tourists to learn about food and food culture at different destinations (Hall \& Sharples, 2003; Brown, 2010; Montella, 2017). 
However, our qualitative data reveals the lack of a chef and gourmet-centred marketing technique in culinary destination marketing in Turkey. The main reason for this situation is the fact that Turkish chefs and gourmets are interested in international cuisine rather than national cuisine. $\mathbf{C}_{\mathbf{3}}$ clearly explained it with the following statements: "A French do not cook a Turkish dish, neither an Italian or an Indian [...] But we cook their food in Turkey! [...] We must cook our own dishes. This is a mistake; it is an insult. Now, this offends my feelings.' This finding supports the Henderson (2018) statement that using local-chefs rather than nonlocal-chefs satisfies the travellers' search for authenticity in travel destinations.

Along with this, the celebrity's expertise can be used to assess a particular endorsement (Ohanian, 1990). Besides, expertise is acknowledged as one of the positive effects, which plays a significant role in tourists' intentions to travel to specific destinations (Veen \& Song, 2014). Celebrity chefs and gourmets lead the community's' nutritional habits with their own expertise (Henderson, 2011; Lane \& Fisher, 2015). Participants have also underscored their changing social status role in educating society on culinary experiences. $\mathbf{G}_{4}$ mentioned: 'People receive misinformation about many foods and they do not know how to properly choose, prepare, cook and store them. Therefore, gourmets and chefs are food and beverage teachers of the community with the wisdom they have achieved as a result of their own experiences.' The changed social status of celebrity chefs and gourmets has been pointed out in some recent studies (e.g., Pizam, 2016; Taspinar \& Temeloglu, 2018).

\section{Reliability}

There is no regulation on what celebrities can share regarding food and nutritional knowledge and that reveals the importance of this role (Jones, Freeth, \& Costa, 2013). However, almost every chef and gourmet aspires to reach a high level of success in their industry. Yet, becoming a famous, well-known person can burden them with serious responsibilities such as; telling the truth, being objective or not to deceive, in short, it requires protection of their credibility. Reliability, one of the important sources of credibility, reveals the objectiveness of chef and gourmet celebrities because the characteristics that relate to their perspective for vilifying or praising a meal while elaborating. Veen (2008) and HalonenKnight and Hurmerinta (2010) mention the importance of choosing the right celebrity endorser in order to avoid the risks of a wrong impression for a product/brand because a consumers' perceptions of the endorsed product/service can be affected both positively or negatively. This situation is mentioned as the double-edged sword (Muda, et al., 2017). Therefore, participants appreciated that using celebrity chefs and gourmets as an advertising tool may put a celebrity's credibility in danger in the view of consumers. In this sense, G1:

"The use of media for promotion is dangerous, especially, using famous authors as a stepping stone for promotional purposes. A good journalist or author should not let himself be used in this regard. I mean to praise or to vilify both good and bad sides of a thing, contradictorily."

Despite this, celebrity endorsements are used as a popular advertising tool in the marketing literature (Erfgen, et al., 2015; Bergkvist \& Zhou, 2016; Pradhan, et al., 2016; Veen \& Song, 2010). But, gourmet participants in the study indicated that they cannot play as much of a role in promoting a restaurant or destination as a chef. Regarding this point, G3's following statement clarifies the issue: 'I think this role belongs more to chefs because we are not the creators of food [...] For example, how right would it be for an art critic to introduce a picture painted by an artist!' 


\section{Supportiveness}

Supportiveness was grouped into two key constructs; localism and match-up as presented in Table 1. The content of this supportiveness is based on giving a boost to native cuisine. The establishment of a gourmet and chef-orientated marketing technique in an integrated manner will benefit the marketing of the local cuisine and therefore the sustainable development of tourism destinations.

\section{Localism}

There is evidence that celebrity chefs and gourmets are more likely to use local foods, which are genuinely grown in a specific destination due to the climatic features of the destination. All participants indicated that their main aim is to promote local food and menus. In this vein, $\mathbf{C} \mathbf{1}$ commented:

\section{"I'm working for this entirely [...] For the next generation to know them, not to forget. Because one day we will definitely return and know all our food again."}

Thus, promoting and marketing destination-specific food and beverages needs a sustainable understanding (Montella, 2017; Rinaldi, 2017). According to Karaosmanoglu (2007), the sustainability of a national cuisine can be obtained with joint studies of educational institutions, chefs, food writers, and gourmets. Participants also indicated the importance of the destination climatic characteristics and local food, which are grown in that climate. C9 stated:

"The most important nutrition method in Turkey is seasonal nutrition. It is an important shame when restaurants do not do it while mothers are doing it at home. For England and America, this is not very important, they already apply the cooking style in one season, but it is a matter for France or Spain [...] Therefore, I think people living in Turkey do not need the deep freeze."

This study also revealed that celebrities in the food market have a tendency to recommend the territorial taste of the destinations. According to Karaosmanoglu (2013), national or ethnic identities that are supported through the cuisine and restaurants can be seen as places of this ethnic origin expression. In this vein, participants were also asked about what kind of food they generally recommend. It highlighted that celebrity chefs and gourmets generally recommend the long-lasting and harmonious flavours which belong to their geographic location. C1o mentioned: 'My own taste and cooking suits Eastern Anatolian cuisine. Therefore, bitter and sour tastes are my interests. For this reason, I recommend to followers the foods where bitter and sour tastes meet as a flavour.' In several studies (e.g., Johnston \& Cairns, 2009; Everett, 2016; Onorati \& Giardullo, 2020), reveal that the most important part of the celebrity chefs and gourmets' role is attributed to enhancing the consciousness of destinations regarding their exotic foods. Our qualitative data supported this phenomenon and highlighted further the importance of national cuisine in the culinary destination marketing.

\section{Match-up}

Branding is a value created by the combination of many elements for a tourism destination (Ashton, 2015). This study revealed that chefs and gourmets can be one of these elements and can be attributed as star power in culinary destination marketing (Fuste-Forne, 2018). The general congruence between two things leads to choosing a celebrity endorsement by addressing match-up theory. The celebrity supporting brand confirms brand juxtaposition and removes any contradictions about the choice of the product. Therefore, it is a prominent theory to endorse products (Ang \& Dubelaar, 2006). The celebrity whose image and values are close to the brand of the business or destination for which they endorse holds true matching in order to ensure effective marketing. Based on 'match-up theory' a valid fit generally provides a congruence between parties (Kamins, \& Gupta, 1994). When an appropriate 
celebrity character matches the nature of the destination then, favourable outcomes emerge for advertisements and hence awareness (Veen, 2008; Croy, 2010; Chan, Lee, \& Wong, 2018). As Magnini et al., (2008) state, the right match between the image of celebrity endorser and tourism destination may ensure proper marketing because tourism destination images are extremely vulnerable to unforeseen situational forces. Therefore, in this study, participants were also asked about their role in branding a restaurant and participants appreciated that chefs and gourmets would only have a match-up role rather than directly create a brand in the culinary industry. $\mathbf{C}_{\mathbf{7}}$ commented:

"I believe that sharing my own experience as an expert absolutely affects the restaurants' sales rate, but only if the restaurants' brand can prove the trueness of what is written through their service quality; otherwise it the restaurant will inevitably close after two or three months."

As highlighted in similar endorsement studies (Seno \& Lukas, 2007; McCartney \& Pinto, 2014), this study also revealed that celebrity endorsement has a match-up role rather than a branding role. This role is particularly relevant for new brands (Törn, 2012). $\mathbf{C}_{\mathbf{5}}$ commented:

"I think initially they will be useful in the promotion of a restaurant. In the first step, it can be useful to be heard, to be shown on TV for opening a new location or to be written about in the newspaper. However, I do not think that sharing writing by a celebrity gourmet or chef about a restaurant can have a function for a restaurant to be successful and able to survive."

\section{Conclusion}

The current study has identified and categorized the role of celebrity endorsement drawing on qualitative data from celebrity chefs and gourmets in Turkey. The study reveals how modern media merely diffuses gastronomy related issues on people's minds by celebrity endorsement and shows the role of celebrity chefs and gourmets in capturing the travellers' attention. Unlike other studies in the field, this study combined relevant attributes of celebrity endorsement phenomena including theories and models with the aim of demonstrating the role of celebrity chefs and gourmets in a holistic manner. The results also provided insights to help design and implement appropriate marketing strategies in culinary destination marketing by highlighting three key dimensions: provocativeness, credibility, and supportiveness. The study also proposed the theoretical and practical implications of using celebrity chefs and gourmets as a marketing tool and thereby contributes to the destination marketing literature.

\section{Theoretical contributions}

Considering the widening of understanding for how celebrity endorsement can be utilized for the urgent need of culinary destination marketing, the current paper explored the role of celebrity chefs and gourmets who understandably have a very high opinion of their contribution in culinary destination marketing. Celebrity chefs and gourmets were selected as a sample to explain the role of celebrity endorsement in the destination marketing context because these individuals are the most important and play a substantial role in creating the product (meal) and therefore generate the market. The originality of this study is perhaps one of the first attempts to examine the roles of celebrity gourmets and chefs in culinary destination marketing from the perspective of celebrity chefs and gourmets.

Research exploring the roles of celebrity gourmets and chefs in the culinary destination marketing domain remains scant. The study results also pointed out the lack of using chef and gourmet-orientated marketing of the culinary experience. By building on the culinary destination marketing concept and the body of literature on celebrity endorsement, the study offered timely and significant insights into an important topic. Therefore, this study provides a critical model to assist food and restaurant 
marketers in harnessing the powerful role of celebrity gourmets and chefs in effecting customers in culinary destination marketing.

In particular, this study explained the role of celebrity chefs and gourmets among the three interconnected key dimensions; provocativeness (Constructed by attractiveness and customer engagement), credibility (Constructed by trustworthiness, leading and reliability), and supportiveness (Constructed by localism and match-up). This study, therefore, contributes to the explanation of celebrity endorsement power in culinary destination marketing along with the proposed theoretical model and its relevant construct. The theoretical framework of this study observes the main pillars of celebrity endorsement power by clustering all relevant themes into groups. Therefore, the findings of this study give a leg up to explaining the celebrity phenomena and in that vein, raised its substantiality. Based on the findings, celebrity gourmet and chef-oriented marketing should be considered when developing marketing strategies for promoting food and restaurants. Moreover, this paper highlights the importance of celebrity gourmets and chefs in culinary destination marketing as a critical component in explaining why food, restaurant marketers, and tourism industry operators should recognize the importance of these individuals while planning marketing strategies. Thus, this study contributes to the body of knowledge on food, restaurants and therefore destination marketing.

\section{Practical implications}

The role of celebrity should not be ignored in advertising due to the large celebrity networks. Featuring celebrities in marketing can attract consumers' attention more easily than a standard advertisement and can build credibility to enhance awareness of brands and reach new consumer segments (Fath, et al., 2017). As a marketing tool, celebrity endorsement will likely continue in the future of marketing. One of the major challenges for this marketing activity is to choose the right celebrity as long as there are other stars being introduced into marketing - and in this way, the loop can continue until the next right celebrity emerges. As a role model or a tastemaker, it is obvious that those celebrities can affect the food choice of people regarding the roles identified in this study. By using celebrity chefs and gourmets, destination marketers can translate this star power into better consumer response and higher revisiting volume extensively.

The findings offer a better insight into the importance of these celebrity individuals to become involved in food marketing. Celebrity chefs and gourmets might leverage to promote basic local food and cooking practices, which could lead to support of national cuisines or the development of restaurants that have indigenous food. Within this context, the development of a chef and gourmet-orientated marketing technique may also provide benefits for the marketing of national cuisine and thus the sustainable development of tourism destinations.

Moreover, food and restaurant managers should pay attention to shared experiences of those celebrity gourmets and chefs and observe the effects of the attitude and behaviour of people who follow those celebrity gourmets and chefs; thereby it will enable them to identify whom they should target and how they can attract those targeted customers. The research model will assist them to map out their distinctive marketing strategies to achieve and maintain a superior competitive position in the food and restaurant industry. Moreover, these individuals refer to well-known personalities around the world who enjoy public recognition (Speck et al., 1988), claiming their celebrity status at the global level by broadcasting tv programs (Jones, 2009) and their well-known personality provides benefits in promotion of a destination (Holloway \& Robinson, 1995). In this way, they make restaurants attractive for tourist visits by presenting a destination's specific cuisine or foods via welcoming messages. 


\section{Limitations and future research}

As with all academic research, this study has some limitations. First, the data was collected from celebrity gourmets and chefs from Turkey, further research should consider more diverse samples, including gourmets and chefs from other countries. Second, the actual roles of the shared experiences of the gourmets and chefs were not measured in the present study. This may be an interesting area for further research. Lastly, considering the immaturity of research on culinary destination marketing, the current study is explorative in nature and based on the views of the chefs and gourmets themselves, who may have a considerably high opinion of their contribution to culinary destination marketing. Therefore, the findings should be verified using quantitative methods to enhance the generalizability of the results. Exploring the relationship between these constructs which determined in this study and adopting them within innovative research design by using quantitative methods is therefore necessary.

\section{Acknowledgment}

An earlier version of this paper was presented at the $4^{\text {th }}$ International Congress of Tourism \& Management Researches - 2017, Girne, Turkish Republic of Northern Cyprus, May 2017

\section{References}

Abidin, A., Panchal, J., \& Thirumaran, K. (2017). Celebrity chefs and the enhancement of culinary tourism experiences in Singapore. In Balancing Development and Sustainability in Tourism Destinations (pp. 109-115). Singapore: Springer.

Agrawal., J., \& Kamakura, W. (1995). The economic worth of celebrity endorsers: An event study analysis. Journal of Marketing, 59, 56-62.

Amos, C., Holmes, G., \& Strutton, D. (2008). Exploring the relationship between celebrity endorser effects and advertising effectiveness: a quantitative synthesis of effect size. International Journal of Advertising, 27(2), 209-234.

Andrew, S., Jeffrey M. P., \& Goldstein, D. (2010). food scholarship and food writing. Food, Culture $\mathcal{E}$ Society, 13(3), 319-329, DOI: 10.2752/175174410X12699432700827s.

Ang, L., \& Dubelaar, C. (2006). Explaining celebrity match-up: co-activation theory of dominant support. In M. Craig Lees, T. Davis, \& G. Gregor (Ed.), AP - Asia-Pacific Advances in Consumer Research (pp. 378-384). Sydney, Australia: Association for Consumer Research.

Ashton, A. S. (2015). Developing a tourist destination brand value: the stakeholders' perspective, tourism planning \& development, 12(4), 398-411, DOI: 10.1080/21568316.2015.1013565.

Atkin, C., \& Block, M. (1983). Effectiveness of celebrity endorsers. Journal of Advertising Research, 23(1), 57-61.

Barnes, C. (2017). Mediating good food and moments of possibility with Jamie Oliver: Problematising celebrity chefs as talking labels. Geoforum, 84, 169-178.

Bergkvist, L., \& Zhou, K. (2016). Celebrity endorsements: a literature review and research agenda. International Journal of Advertising, 35(4), 642-663.

Berkman, H. W., \& Gilson, C. (1986). Consumer behaviour: concepts and strategies. Kent Publishing Company.

Björk, P., \& Kauppinen-Räisänen, H. (2016). Local food: A source for destination attraction. International Journal of Contemporary Hospitality Management, 28(1), 177-194.

Boyne, S., Hall, D., \& Williams, F. (2003). Policy, support, and promotion for food-related tourism initiatives. Journal of Travel \& Tourism Marketing, 14(3-4), 131-154.

Braun, V., \& Clarke, V. (2006). Using thematic analysis in psychology. Qualitative Research in Psychology, 3(2), 77-101. 
Brien, D. (2011). Margaret Fulton: A study of a 1960s Australian food writer as an activist. Coolabah (5), $72-82$.

Brown, C. (2010). Wine tourism: A serious leisure approach. Journal of Service Science, 3(1), 29-34.

Burusnukul, P., Binkley, M. \& Sukalakamala, P. (2011). Understanding tourists' patronage of Thailand foodservice establishments: an exploratory decisional attribute approach. British Food Journal, $113(8), 965-981$.

Cetin, G., \& Bilgihan, A. (2016). Components of cultural tourists' experiences in destinations. Current Issues in Tourism, 19(2), 137-154.

Chan, G. S., Lee, A., \& Wong, C. (2018). Celebrity endorsement in the advertisement on destination choice among generation Y in Hong Kong. International Journal of Marketing Studies, 10(2), 16-27.

Chen, Y.-S., Raab, C., \& Chen, C.-C. (2017). The influence of celebrity chefs on restaurant customers' behaviour. Journal of Hospitality Marketing, 26(5), 489-510.

Choe, J. Y., \& Kim, S. (2018). Effects of tourists' local food consumption value on attitude, food destination image, and behavioural intention. International Journal of Hospitality Management, 71, 1-10.

Choi, S. M., \& Rifon, N. J. (2007). Who is the celebrity in advertising? Understanding the dimensions of celebrity images. Journal of Popular Culture, 40, 304- 324.

Choi, S. M., \& Rifon, N. (2012). It is a match: the impact of congruence between celebrity image and consumer ideal self on endorsement effectiveness: celebrity endorsement and self-concept. Psychology \& Marketing, 9, 639-650.

Clarke, T. B., Murphy, J., \& Adler, J. (2016). Celebrity chef adoption and implementation of social media, particularly Pinterest: A diffusion of innovations approach. International Journal of Hospitality Management, 57, 84-92.

Creswell, J. W. (2007). Qualitative inquiry and research design: choosing among five approaches. Thousand Oaks: CA: Sage.

Croy, W. G. (2010). Planning for film tourism: Active destination image management. Tourism and Hospitality Planning \& Development, 7(1), 21-30.

Coughlan, L.-M., \& Saayman, M. (2018). The importance of different culinary aspects when traveling the case of international tourists to South Africa. European Journal of Tourism Research, 18, 95-119.

Doss, S. (2011). The transference of brand attitude: the effect on the celebrity endorser. Journal of Management and Marketing Research, 7 (1), 58-70.

Dwivedi, A., Johnson, L. W., \& McDonald, R. (2016). Celebrity endorsements, self-brand connection, and relationship quality. International Journal of Advertising, 35(3), 486-503.

Elo, S., \& Kyngas, H. (2008). The qualitative content analysis process. Journal of Advanced Nursing, 62 (1), 107-115.

Erdogan, B. Z. (1999). Celebrity endorsement: a literature review. Journal of Marketing Management, 15(4), 291-314.

Erdogan, B. Z., \& Baker, M. (200o). Towards a practitioner-based model of selecting celebrity endorsers. International Journal of Advertising, 19(1), 25-42.

Erfgen, C., Zenker, S., \& Sattler, H. (2015). The vampire effect: when do celebrity endorsers harm brand recall? International Journal of Research in Marketing, 32, 155-163.

Essays, U. (2018, November). Use of celebrities in advertising. Retrieved from https://www.ukessays.com/essays/marketing/use-of-celebrities-in-advertising-marketingessay.php?vref=1.

Everett, S., \& Aitchison, C. (2008). The role of food tourism in sustaining regional identity: a case study of Cornwall, southwest England. Journal of Sustainable Tourism, 16 (2), 150-167.

Everett, S. (2016). Food and Drink Tourism. Thousand Oaks, CA: SAGE Publications. 
Fath, B. P., Fiedler, A., Li, Z., \& D. Hugh, W. (2017). Collective Destination Marketing in China: Leveraging Social Media Celebrity Endorsement. Tourism Analysis, 22, 377-387.

Fodness, D., \& Murray, B. (1998). A typology of tourist information search strategies. Journal of Travel Research, 1, 108-119.

Fuste-Forne, F. (2019). Star Chefs and the Table: From Restaurant to Home-Based Culinary Experiences, Journal of Culinary Science \& Technology, DOI: 10.1080/15428052.2018.1563933.

Glaser, B. G., \& Strauss, A. (1967). The discovery of grounded theory: strategies for qualitative research (NY: Aldine b.). New York.

Glover, P. (2009). Celebrity endorsement in tourism advertising: effects on destination image. Journal of Hospitality and Tourism Management, 16, 16-23.

Gummersson, E. (2000). Qualitative methods in research management (2nd ed.). Thousand Oaks: CA: Sage.

Hall, C. M., \& Mitchell, R. (200o). We are what we eat: tourism, culture and the globalisation and localisation of cuisine. Tourism Culture and Communication, 2(1), 29-37.

Hall, C. M., \& Sharples, L. (2003). The consumption of experiences or the experiences of consumption? An introduction to the tourism of taste. In C. M. Hall, E. Sharples, R. Mitchell, N. Macionis, \& B. Camb (Eds.), Food Tourism Around the World: Development, Management, and Markets (pp. 1-24). Oxford: Butterworth-Heinemann.

Halonen-Knight, E., \& Hurmerinta, L. (2010). Who endorses whom? Meanings transfer in celebrity endorsement. Journal of Product \& Brand Management, 19(6), 452-460.

Henderson, J. C. (2011). Celebrity chefs: expanding empires. British Food Journal, 13(5), 613-624.

Henderson, J. C. (2018). Western Celebrity Chefs and Restaurants: A View from Singapore. APJIHT, 7(2), $51-67$.

Holloway, J., \& Robinson, C. (1995). Marketing for tourism (3rd ed.). Harlow: Longman.

Hong Kong Tourism Board. (2020, 02 19). Exciting Events: Hong Kong Wine E Dine Month. Retrieved from http://www.discoverhongkong.com/eng/about-hktb/annual-report/annual-report-20152016 /strategic-focus/exciting-event/?gotoTarget=hong-kong-wine-and-dine-month.

Jain, V., \& Roy, S. (2016). Understanding meaning transfer in celebrity endorsements: a qualitative exploration. Qualitative Market Research: An International Journal., 19(3), 266-286.

Jensen, Ø., \& Hansen, K. (2007). Consumer values among restaurant customers. International Journal of Hospitality Management (26), 603-622.

Johnston, J., \& Cairns, K. (2009). The national and the cosmopolitan in cuisine: constructing America through gourmet food writing. In D. Inglis, \& D. Gimlin (Eds.), The globalization of food (pp. 161183). Oxford: Berg.

Johnston, J., Rodney, A., \& Chong, P. (2014). Making change in the kitchen? A study of celebrity cookbooks, culinary personas, and inequality. Poetics, 47, 1-22.

Jones, M. T. (2009). A celebrity chef goes global: the business of eating. Journal of Business Strategy, 30(5), 14-23.

Jones, M., Freeth, E., \& Costa, R. (2013). A systematic cross-sectional analysis of British based celebrity chefs' recipes. is there cause for public health concern? Food and Public Health, 3(2), 100-110.

Kamins, A. M. (1990). An investigation into the 'match-up' hypothesis in celebrity advertising: when beauty may be only skin deep. Journal of Advertising, 19(1), 4-13.

Kamins, M. A. (1989). Celebrity and non-celebrity advertising in a two-sided context. Journal of Advertising Research, 29(3), 34-42.

Kamins, M. A., \& Gupta, K. (1994). Congruence between spokesperson and product type: a matchup hypothesis perspective. Psychology \& Marketing, ${ }_{11}(6)$, 569-586.

Karaosmanoğlu, D. (2007). Surviving the global Market-Turkish cuisine under construction. Food, Culture E Society, 10(3), 426-448. 
Karaosmanoglu, D. (2013). Globalised cuisine, non-national identities, and the individual: staging Turkishness in Turkish- speaking restaurants in London. Journal of Intercultural Studies, 34(4), 371-386, http://dx.doi.org/10.1080/07256868.2013.807228.

Karim, S., \& Chi, C. (2010). Culinary tourism as a destination attraction: an empirical examination of destinations' food image. Journal of Hospitality Marketing and Management, 19(6), 531-555.

Ketchen, J., Adams, G., \& Shook, C. (2008). Understanding and managing CEO celebrity. Business Horizons, 51, 529-534.

Kim, J.-H. (2018). The impact of memorable tourism experiences on loyalty behaviours: the mediating effects of destination image and satisfaction. Journal of Travel Research, 57 (7), 856-870.

Kim, S. S., Lee, J., \& Prideaux, B. (2014). Effect of celebrity endorsement on tourists' perception of corporate image, corporate credibility, and corporate loyalty. International Journal of Hospitality Management, 37, 131-145.

Kim, S., Wang, G., \& Ahn, T. (2013). Which endorser and content are most influential in Korean restaurant promotions? International Journal of Hospitality Management, 33, 208-218.

Kivela, J., \& Crotts, J. (2005). Gastronomy tourism. Journal of Culinary Science E Technology, 4(2-3), 3955 .

Knittel, C. R., \& Stango, V. (2014). Celebrity endorsements, firm value, and reputation risk: evidence from the tiger woods scandal. Management Science, 6o(1), 21-37.

Koerning, S., \& Boyd, T. (2009). To catch a tiger or let him go: the match-up effect and athlete endorsers for sport and non-sport brands. Sport Marketing Quarterly, 18(1), 25-37.

Kotler, P. (200o). Pazarlama Yönetimi. İstanbul: Millenium Baskı, Beta Yayınları.

Kotler, P., Bowen, J., \& Makens, J. (2006). Marketing for hospitality and tourism. New Jersey- Amerika: Pearson Educational International.

Lane, C. (2013). Tastemakers in the "fine-dining" restaurant industry: The attribution of aesthetic and economic value by gastronomic guides. Poetics, 41, 342-365.

Lane, S. R., \& Fisher, S. (2015). The influence of celebrity chefs on a student population. British Food Journal, $117(2), 614-628$.

Larsen, S. (2007). Aspects of a psychology of the tourist experience. Scandinavian Journal of Hospitality and Tourism, 7, 7-18.

Larson, L.R. and Poudyal, N.C., 2012. Developing sustainable tourism through adaptive response management: a case study of Machu Picchu, Peru. Journal of Sustainable Tourism, 20 (7), 917-938.

Lee, S., Scott, D., \& Kim, H. (2008). Celebrity fan involvement and destination perceptions. Annals of Tourism Research, 35(3), 809-832.

Lochrie, S., Baxter, I., Collison, E., Curran, R., Gannon, M., Taheri, B., Yalinay, O. (2019). Self-expression and play: Can religious tourism be hedonistic? Tourism Recreation Research, In Press.

Magnini, V. P., Honeycutt, E., \& Cross, A. (2008). Understanding the use of celebrity endorsers for hospitality firms. Journal of Vacation Marketing, 14(1), 57-69.

Magno, F., \& Cassia, F. (2018). The impact of social media influencers in tourism, Anatolia, 29:2, 288290, DOI: 10.1080/13032917.2018.1476981

Marshall, R., Na, W., State, G., \& Deuskar, S. (2008). Endorsement Theory: How Consumers Relate to Celebrity Models. Journal of Advertising Research, 48, 564-572.

McCartney, G., \& Pinto, J. (2014). Influencing Chinese travel decisions: the impact of celebrity endorsement advertising on the Chinese traveller to Macao. Journal of Vacation Marketing, 20(3), 253-266.

McCracken, G. (1989). Who is the celebrity endorser? cultural foundation of the endorsement process. Journal of Consumer Research, 16, 310-321.

McGuire, W. J. (1985). The nature of attitudes and attitude change. In G. Lindzey \& Aronson, E. (Eds.), Handbook of Social Psychology (pp. 136-314). MA: Addison Wesley. 
Mckrecher, B., Okumuş, F., \& Okumuş, B. (2008). Food tourism as a viable market segment: it's all how you cook the numbers. Journal of Travel \& Tourism Marketing, 2(2), 137-148.

Mishra, A. S., Roy, S., \& Bailey, A. A. (2015). Exploring brand personality-celebrity endorser personality congruence in celebrity endorsements in the Indian context. Psychology $\mathcal{E}$ Marketing, 32(12), 11581174. DOI:10.1002/mar.2015.32.issue-12.

Montella, M. M. (2017). Wine tourism and sustainability: a review. Sustainability 2017, 9(113), 1-11.

Muda, M., Musa, R., \& Putit, L. (2017). Celebrity endorsement in advertising: a double-edged sword. Journal of ASIAN Behavioural Studies, 2(3), 21-32.

Nelson, V. (2015) Place reputation: representing Houston, Texas as a creative destination through culinary culture, Tourism Geographies, 17(2), 192-207, DOI: 10.1080/14616688.2014.986751.

Nelson, V. (2016) Peru's image as a culinary destination, Journal of Cultural Geography, 33 (2), 208-228, DOI: 10.1080/o8873631.2016.1153269.

Ohanian, R. (1990). Construction and validation of a scale to measure celebrity endorsers' perceived expertise, trustworthiness, and attractiveness. Journal of Advertising, 14 (3), 390-414.

Ohanian, R. (1991). The impact of celebrity spokespersons' perceived image on consumer's intention to purchase. Journal of Advertising Research, 31(1), 46-54.

Okumus, B., \& Cetin, G. (2018). Marketing Istanbul as a culinary destination. Journal of Destination Marketing E Management, 9, 340-346.

Okumus, B., Okumus, F., \& McKercher, B. (2007). Incorporating local and international cuisines in the marketing of tourism destinations: the cases of Hong Kong and Turkey. Tourism Management, 28, 253-261.

Okumus, F., Kock, G., Scantlebury, M. M., \& Okumus, B. (2013). Using local cuisines when promoting small Caribbean island destinations. Journal of Travel E Tourism Marketing, 30(4), 410-429.

Onorati, M. G., \& Giardullo, P. (2020). Social media as taste re-mediators: emerging patterns of food taste on TripAdvisor, Food, Culture \& Society, DOI: 10.1080/15528014.2020.1715074.

Park, C. (2004). Efficient or enjoyable? consumer values of eating-out and fast food restaurant consumption in Korea. International Journal Hospitality Management (23), 87-94.

Rachao, S., Breda, Z., Fernandes, C., \& Joukes, V. (2019). Food tourism and regional development: A systematic literature review. European Journal of Tourism Research, 21, 33-49.

Patton, M. (2002). Qualitative research and evaluation methods. Thousand Oaks: CA: Sage.

Pawaskar, R. P., \& Goel, M. (2016). Improving the efficacy of destination marketing strategies: a structural equation model for leisure travel. Indian Journal of Science and Technology, 9(15), 1-11.

Phillips, D. R., Cheng, K. H., Yeh, A. G., \& Siu, O.-L. (2010). Person-environment (P-E) fit models and psychological well-being among older persons in hong kong. Environment and Behaviour, 42(2), 221-242.

Powell, H., \& Prasad, S. (2007). Life swap: celebrity expert as lifestyle adviser. In D. Heller (Ed.), Makeover Television (pp. 56-66). London: I.B.Tauris \& Co Ltd.

Powell, H., \& Prasad, S. (2010). "As seen on Tv." the celebrity expert: how to taste is shaped by lifestyle media. Cultural Politics, 6(1), 111-124.

Pradhan, D., Duraipandian, I., \& Sethi, D. (2016). Celebrity endorsement: how celebrity-brand-user personality congruence affects brand attitude and purchase intention. Journal of Marketing Communication, 22(5), 456-473.

Priester, J. R., \& Petty, R. (2003). The influence of spokesperson trustworthiness on message elaboration, attitude strength, and advertising effectiveness. Journal of Consumer Psychology, 3(4), 408-421.

Rinaldi, C. (2017). Food and gastronomy for sustainable place development: a multidisciplinary analysis of different theoretical approaches. Sustainability, 9, 2-25.

Pizam, A. (2016). The changing social status of chefs. International Journal of Hospitality Management, 59, 116-117. 
Rinka, X. X. \& Pratt, S. (2018). Social media influencers as endorsers to promote travel destinations: an application of self-congruence theory to the Chinese Generation Y, Journal of Travel $\mathcal{E}$ Tourism Marketing, DOI:10.1080/10548408.2018.1468851.

Robinson, R., \& Getz, D. (2014). Profiling potential food tourists: an Australian study. British Food Journal., 116(4), 690-706.

Roy, S. (2018). Meaning transfer in celebrity endorsements: an explanation using metaphors. Journal of Marketing Communications, 24(8), 843-862.

Sanchez, J., Callarisa, L., Rodriguez, R., \& Moliner, M. (2006). The perceived value of the purchase of a tourism product. Tourism Management, (27), 394-409.

Seno, D., \& Lukas, B. (2007). The equity effect of product endorsement by celebrities: a conceptual framework from a co-branding perspective. European Journal of Marketing, 41(1/2), 121-134.

Sirgy, M. J. (2018). Self-congruity theory in consumer behaviour: A little history. Journal of Global Scholars of Marketing Science, 28(2), 197-207.

Smith, S., \& Costello, C. (2009). Segmenting visitors to a culinary event: motivations, travel behaviour, and expenditures. Journal of Hospitality Marketing E Management, 18(1), 44-67.

Solnick, S. J., \& Schweitzer, M. (1999). The influence of physical attractiveness and gender on ultimatum game decisions. Organizational Behaviour and Human Decision Processes, 79(3), 199-215.

Sotiriadou, P., Brouwers, J., \& Le, T. (2014). Choosing A qualitative data analysis tool: a comparison of Nvivo and Leximancer. Annals of Leisure Research, 17(2), 218-234.

Speck, P., Schumann, D., \& Thompson, C. (1988). Celebrity Endorsements - Scripts, Schema, And Roles: Theoretical Framework and Preliminary Tests. Advances in consumer research, 15, 69-76.

Svejenova, S., Slavich, B., \& Abdelgawad, S. (2015). Creative entrepreneurs: the business models of haute cuisine chefs. In M. L. Candace Jones (Ed.), The Oxford Handbook of Creative Industries (pp. 184199). Oxford, UK: Oxford University Press.

Taspinar, O., \& Temeloglu, E. (2018). Influence of Tv Cooking Shows on the Behavioural Intention of Participating in Gastronomic Tourism. Journal of Tourism and Gastronomy Studies, 6(8), 24-40.

Till, B. D., \& Busler, M. (200o). The match-up hypothesis: physical attractiveness, expertise, and the role of fit on brand attitude purchase intent and brand beliefs. Journal of Advertising, 29(3), 1-13.

Till, B. D., \& Shimp, T. (1998). Endorsers in advertising: the case of negative celebrity information. Journal of Advertising, XXVII(1), 67-82.

Törn, F. (2012). Revisiting the match-up hypothesis: effects of brand-incongruent celebrity endorsements. Journal of Current Issue \& Research in Advertising, 33(1), 20-36.

Trubek, A. B. (2008). The taste of place: a cultural journey into terroir. London: University of California Press.

Tsai, C.-T. \& Wang, Y.-C. (2017). Experiential value in branding food tourism. Journal of Destination Marketing \& Management, 6, 56-65.

Van Der, R., \& Song, H. (2014). Impact of The Perceived Image of Celebrity Endorsers on Tourists' Intentions to Visit. Journal of Travel Research, 53(2), 211-224.

Veen, R. v. (2008). Analysis of the implementation of celebrity endorsement as a destination marketing instrument. Journal of Travel E Tourism Marketing, 24(2-3), 213-222.

Veen, R. v., \& Song, H. (2010). Exploratory study of the measurement scales for the perceived image and advertising effectiveness of celebrity endorsers in a tourism context. Journal of Travel $\mathcal{E}$ Tourism Marketing, 27(5), 460-473.

Veen, R. v., \& Song, H. (2014). Impact of the perceived image of celebrity endorsers on tourists' intentions to visit. Journal of Travel Research, 53(2), 211-224.

Weir, R. J., \& Weir, R. (2015). The power of celebrity: exploring the basis for Oprah's successful endorsement of Australia as a vacation destination. Journal of Vacation Marketing, 21(2), 117-130. 
White, D. W., Goddard, L., \& Wilbur, N. (2009). The effects of negative information transference in the celebrity endorsement relationship. International Journal of Retail E Distribution Management, $37(4), 322-335$.

Whiting, J., \& Hannam, K. (2015). Creativity, self-expression, and leisure. Leisure studies, 34(3), 372-384.

Yang, W. (2018). Star Power: The evolution of celebrity endorsement research. International Journal of Contemporary Hospitality Management, 30(1), 389-415.

Yen, C. H., \& Teng, H. (2015). Celebrity involvement, perceived value, and behavioural intentions in popular media-induced tourism. Journal of Hospitality $\mathcal{E}$ Tourism Research, 39(2), 225-244.

Yen, C.-H., \& Croy, W. (2016). Film tourism: celebrity involvement, celebrity worship, and destination image. Current Issues in Tourism, 19(10), 1027-1044.

Received: 27/11/2019

Accepted: 29/02/2020

Coordinating editor: Stanislav Ivanov 